Рощик І. А., к.е.н., доцент (Національний університет водного господарства та природокористування, м. Рівне)

\title{
ТРАНСФОРМУВАННЯ ЕКОНОМІЧНИХ МЕХАНІЗМІВ ПІДВИЩЕННЯ ЕФЕКТИВНОСТІ ВИКОРИСТАННЯ ВОДНИХ РЕСУРСІВ
}

Досліджено сутність поняття «ефективність використання водних ресурсів». Узагальнено теоретичні засади трансформування економічних механізмів водокористування 3 метою підвищення його ефективності. Здійснено порівняльний аналіз ефективності використання водних ресурсів в Україні та країнах Європи. Визначено цінову еластичність попиту на воду в Україні. Обгрунтовано напрямки трансформування економічних механізмів водокористування 3 метою підвищення його ефективності: впровадження нецінових механізмів, прогресивна шкала рентної плати за спецводокористування і тарифів на водопостачання і водовідведення, цільове призначення рентної плати.

Ключові слова: ефективність, водомісткість, водовіддача, цінова еластичність попиту, економічний механізм, рентна плата, тариф, ліміт.

Постановка проблеми. Підвищення ефективності використання

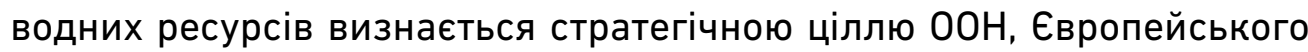
Союзу [1] і України [2; 3].

Хоча в Україні проблема питної води не $є$ надзвичайно гострою, вона відноситься до країн з низькою за світовими стандартами і 3 найнижчою в Європі поряд з Кіпром і Мальтою забезпеченістю водою. Тому підвищення ефективності використання водних ресурсів $\epsilon$ досить актуальним.

Незважаючи на вище зазначене, ефективність використання водних ресурсів в Україні щонайменше втричі менша, ніж в «найбідніших» європейських країнах, а нині діючі економічні механізми не містять адекватних стимулів її підвищення.

Аналіз останніх досліджень. Попри на значну кількість наукових праць з управління водними ресурсами, більшість з них розглядає екологічні аспекти управління (А.В. Яцик). Серед економічних проблем розкриваються переважно фіскальні наслідки (В.А. Голян, H.Е. Ковшун, Я. Котляревський), переваги і недоліки економічних механізмів водокористування (В.М. Тищенко, М.Є. Стадник), продуктивність водокористування (Б.М. Данилишин, М.А. Хвесик), управління 
водогосподарськими проектами (Л.Ф. Кожушко, Р.М. Костюкевич).

Водночас напрями використання економічних механізмів як факторів підвищення ефективності використання водних ресурсів залишаються недостатньо обгрунтованими.

Мета і завдання дослідження - обґрунтування напрямів трансформування економічних механізмів 3 метою підвищення ефективності водокористування.

Виклад основного матеріалу. Ефективність використання водних ресурсів - це здатність системи отримувати максимально можливий економічний ефект від використання водних ресурсів за умов дотримання меж екологічної стійкості [4; 5].

На думку як вітчизняних, так і зарубіжних вчених, оцінювати ефективність водокористування можна за одним із взаємообернених показників - водомісткість та водовіддача (табл. 1).

Таблиця 1

Показники ефективності використання водних ресурсів [5; 6]

\begin{tabular}{|c|c|c|c|}
\hline $\begin{array}{l}\text { № } \\
3 / \pi\end{array}$ & Назва показника & Зміст & $\begin{array}{c}\text { Методика } \\
\text { визначення }\end{array}$ \\
\hline 1. & \begin{tabular}{|lr} 
Водомісткість & (інтенсивність \\
використання & водних \\
ресурсів, water use efficiency)
\end{tabular} & $\begin{array}{l}\text { затрати води у розрахунку } \\
\text { на одиницю обсягів товарів } \\
\text { i послуг }\end{array}$ & \begin{tabular}{|l} 
співвідношення \\
затрат води до \\
обсягів продукції
\end{tabular} \\
\hline 2. & \begin{tabular}{|l} 
Водовіддача \\
(водопродуктивність, \\
productivity)
\end{tabular} & $\begin{array}{l}\text { вихід товарів і послуг } \\
\text { системи у розрахунку на } \\
\text { одиницю затрат води }\end{array}$ & $\begin{array}{l}\text { співвідношення } \\
\text { обсягів продукції до } \\
\text { затрат води }\end{array}$ \\
\hline
\end{tabular}

На практиці підвищення ефективності досягається за рахунок удосконалення структури водокористування - пріоритетне стимулювання використання води в тих галузях чи регіонах економіки, де створюються більші обсяги продукції (більша валова додана вартість), а також за рахунок заходів, спрямованих на економне витрачання водних ресурсів і покращення їх якості.

Як свідчить багато досліджень, стимулювати економне водоспоживання (породити мотив до добровільної зміни поведінки в цьому напрямку) можливо за допомогою цінових (тариф, податок, плата, субсидія) та нецінових (обмеження або торгівля правами на водозабір, пряма роздача водоощадних технологій, інформаційна кампанія тощо) економічних механізмів [7, С. 8; 8; 9, С. 6; 10, С. 44].

Цінові механізми вважаються найбільш придатними для досягнення цієї мети, оскільки вони, на відміну від нецінових, впливають на кінцеву вартість водних ресурсів для споживача. Разом з тим, віддавати перевагу ціновим механізмам у регулюванні попиту на воду, варто лише в тих випадках, коли зі збільшенням ціни попит зме- 
ншується порівняно швидшими темпами - еластичність попиту на воду за ціною Е>-1.

В Україні спостерігається висока інтенсивність споживання води для виробничих потреб (81\% забраної води). Так, у 2016 р. водомісткість економіки України у фактичних цінах була майже втричі, а у порівнянних цінах - всемеро більша, ніж Сербії (країни Європи 3 найбільшою водомісткістю $42 \mathrm{~m}^{3} / 1000$ євро) - 3 м м $^{3} 1000$ грн. або $100 \mathrm{~m}^{3} / 1000$ євро (табл. 2, рис. 1).

Таблиця 2

Водомісткість економіки України у 2010-2017 рр. [14; 15]

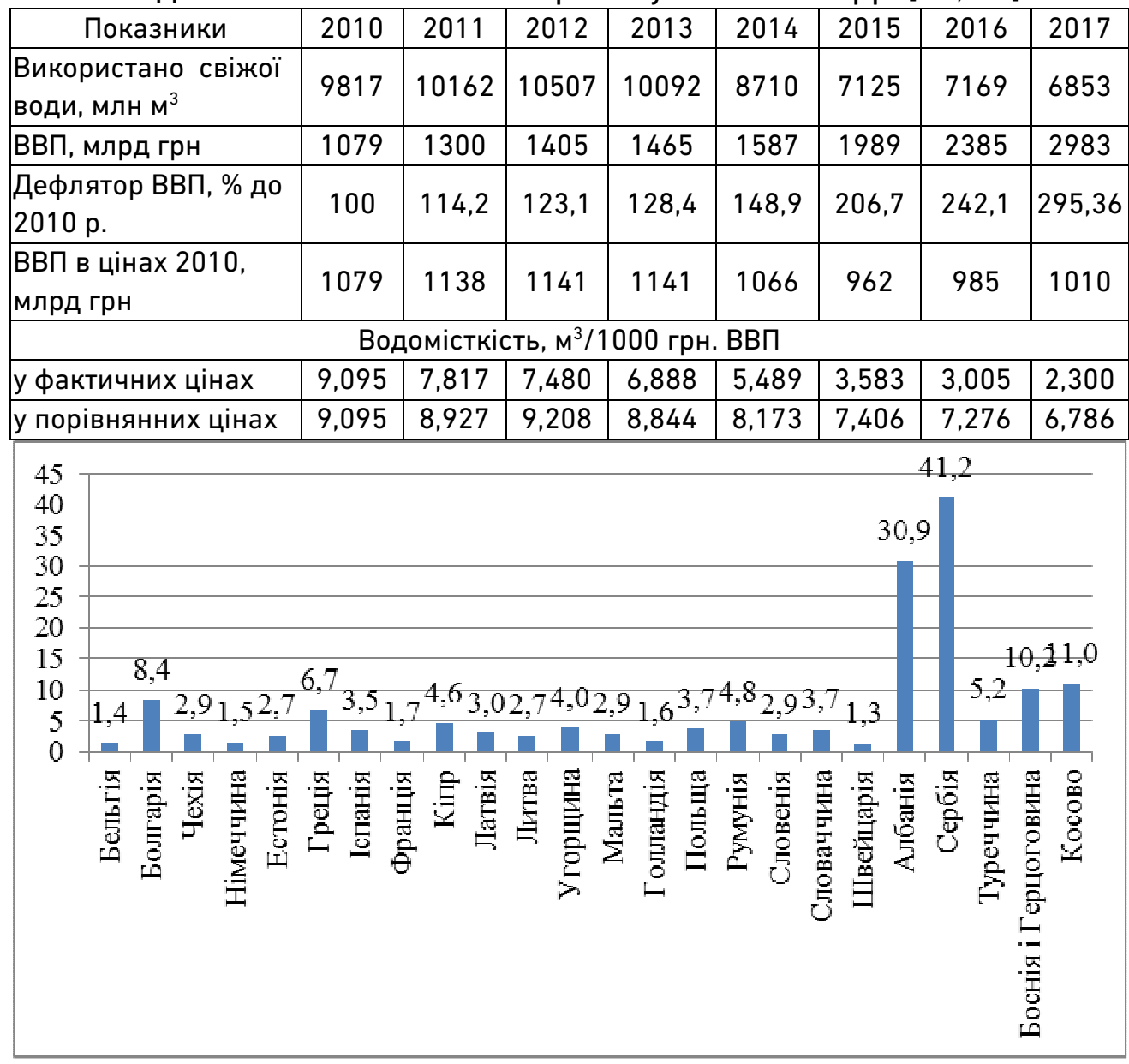

Рис. 1. Водомісткість економіки країн Європи, м³/тис. євро [16]

Відповідно у 2016 році продуктивність водних ресурсів України становила близько 10 євро/м³. Це у 2-3 рази менше, ніж в європейських країнах 3 найменшою продуктивністю використання водних ресурсів - Сербії, Албанії - 24 і 32 євро/м³ (рис. 2). 
Водомісткість економіки за останні 10 років суттєво зменшилася. Основною причиною цього стало, в першу чергу, зменшення обсягів виробництва (на 8,9\% у 2016 р. порівняно з 2010 р.), однак не впровадження водоощадних технологій. Якщо до 2030 р. прогнозувати 30-ти відсоткове підвищення продуктивності використання водних ресурсів, що закладено у «Цілях сталого розвитку: Україна» (ціль 6 «Чиста вода та належні санітарні умови», завдання 6.4. «Підвищити ефективність водокористування»), при одночасному зростанні промислового та сільськогосподарського виробництва, то не варто очікувати суттєвого зменшення потреби суб'єктів підприємництва у воді.

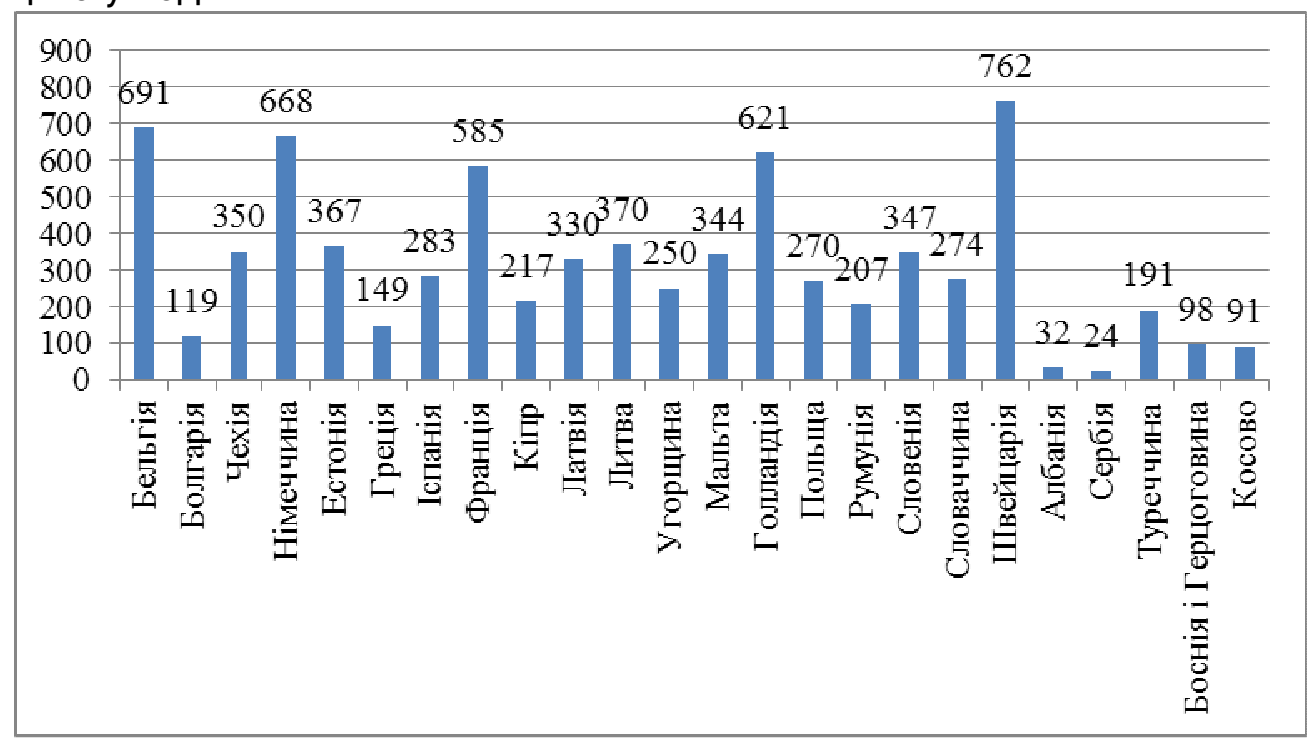

Рис. 2. Продуктивність водних ресурсів в економіці європейських країн у 2016 р., $\epsilon$ вро $/ \mathrm{M}^{3}[16]$

Населення в Україні споживає $17 \%$ усієї забраної води, що становить в середньому 29 м³ води на особу на рік (табл. 3) і відповідає європейській практиці (рис. 4). Однак, все ж таки є багато європейських країн, населення яких експлуатують водні ресурси ощадливіше (Албанія - $4 \mathrm{M}^{3}$ на особу).

Зменшення об'ємів використання води для питних та санітарно-гігієнічних потреб відбулося як під впливом скорочення чисельності населення (з 2010 по 2016 рр. - на 7\%), так і підвищення економності витрачання водних ресурсів, зокрема внаслідок встановлення лічильників. 
Використання свіжої води на питні та санітарно-гігієнічні потреби на душу населення України у 2010-2016 рр. [15; 17]

\begin{tabular}{|l|c|c|c|c|c|c|c|c|}
\hline Показники & 2010 & 2011 & 2012 & 2013 & 2014 & 2015 & 2016 & 2017 \\
\hline $\begin{array}{l}\text { Використано свіжої } \\
\text { води на питні та } \\
\text { санітарно-гігієнічні } \\
\text { потреби, млн м }\end{array}$ & 1917 & 1882,5 & 1848 & 1765 & 1500 & 1267 & 1239 & 1174 \\
\hline $\begin{array}{l}\text { Чисельність } \\
\text { населення, тис. ос. }\end{array}$ & 45962 & 45778 & 45633 & 45553 & 45426 & 42929 & 42761 & 42585 \\
\hline $\begin{array}{l}\text { Використано свіжої } \\
\text { води на питні та } \\
\text { санітарно-гігієнічні } \\
\begin{array}{l}\text { потреби на душу } \\
\text { населення, мос. }\end{array}\end{array}$ & 41,708 & 41,122 & 40,497 & 38,746 & 33,021 & 29,514 & 28,975 & 27,569 \\
\hline
\end{tabular}

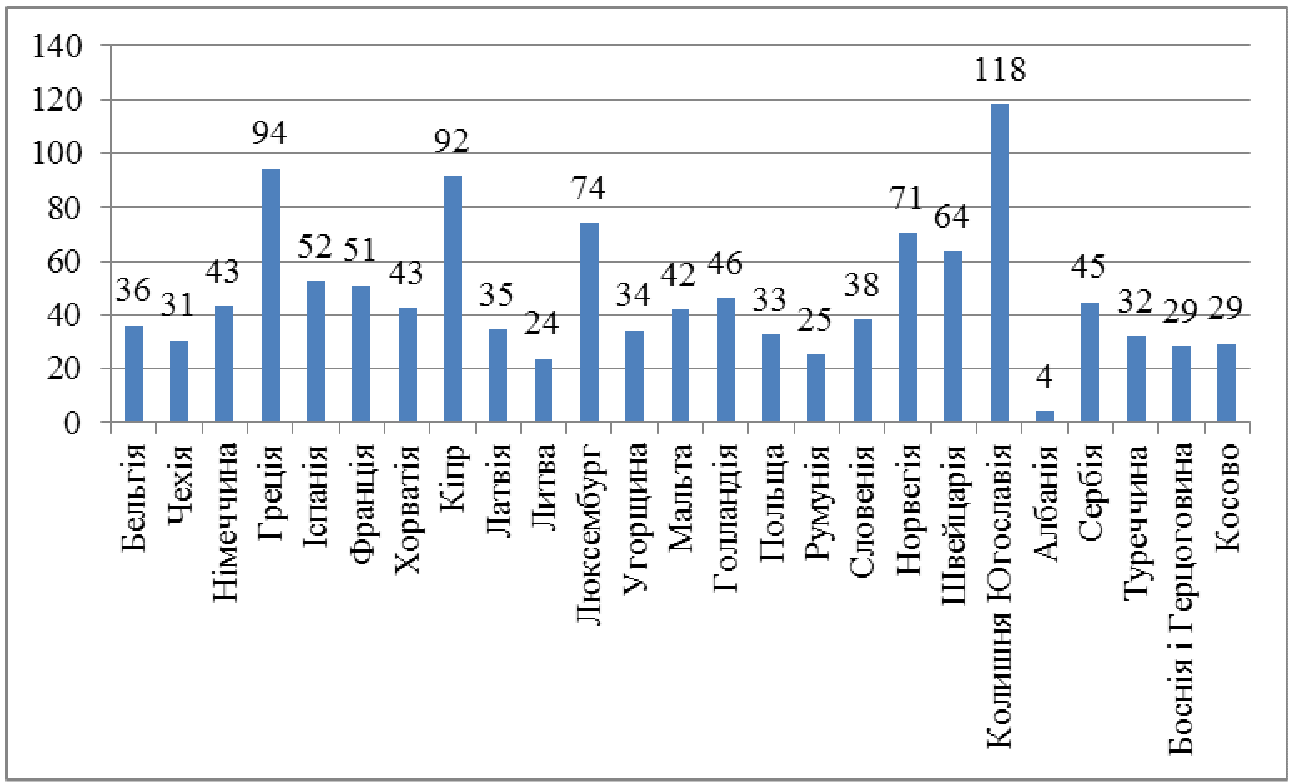

Рис. 3. Використання свіжої води в домогосподарствах Європи на душу населення, м³/oc. [16]

Згідно з прогнозом Інституту демографії та соціальних досліджень НАНУ у 2050 році населення України налічуватиме трохи більше 39 млн осіб, а з прогнозом ООН - трохи більше 33 млн осіб, тобто зменшиться на 8-22\% порівняно з 2018 роком. Отже, найближчим часом можна прогнозувати зменшення використання води для питних та санітарно-гігієнічних потреб. Разом з тим, в Україні ще $є$ невикористані резерви скорочення використання води у розрахунку на 1 жителя до рівня зразкових європейських країн. 
Однією з причин низької ефективності використання водних ресурсів в Україні є чинні економічні механізми управління попитом на воду:

1) рентна плата за спеціальне водокористування;

2) ліміти на спеціальне водокористування;

3) тарифи на водопостачання і водовідведення.

Механізм рентної плати в поєднанні з механізмом лімітування теоретично можуть стимулювати зменшення водоспоживання, оскільки об'єктом обкладання рентою $є$ фактично спожитий обсяг води. Однак, українські рентні ставки в рази менші за європейські і не змінюються за прогресивною шкалою (чинними $є$ тільки два рівні ставок - в межах та за умови перевищення ліміту). При цьому ліміти видаються в адміністративному порядку, а не на конкурентних засадах, безоплатно і $\epsilon$ такими високими, що вкрай рідко водокористувачі допускають їх перевищення [11; 17].

Механізм тарифікації на водопостачання та водовідведення не спонукає постачальників цих послуг знижувати витрати та здійснювати ремонти мереж, оскільки вони є монополістами, а населення більше економити воду, оскільки чинними $є$ уніфіковані, а не прогресивно зростаючі тарифи [12; 13].

Про суттєвий вплив рентної плати за спецводокористування та тарифів на водопостачання і водовідведення свідчать результати кореляційно-регресійного аналізу: варіація попиту на 85 і 89\% пояснюється варіацією ціни, і лише 15 та $11 \%$ - іншими факторами (рис. 4, 5).

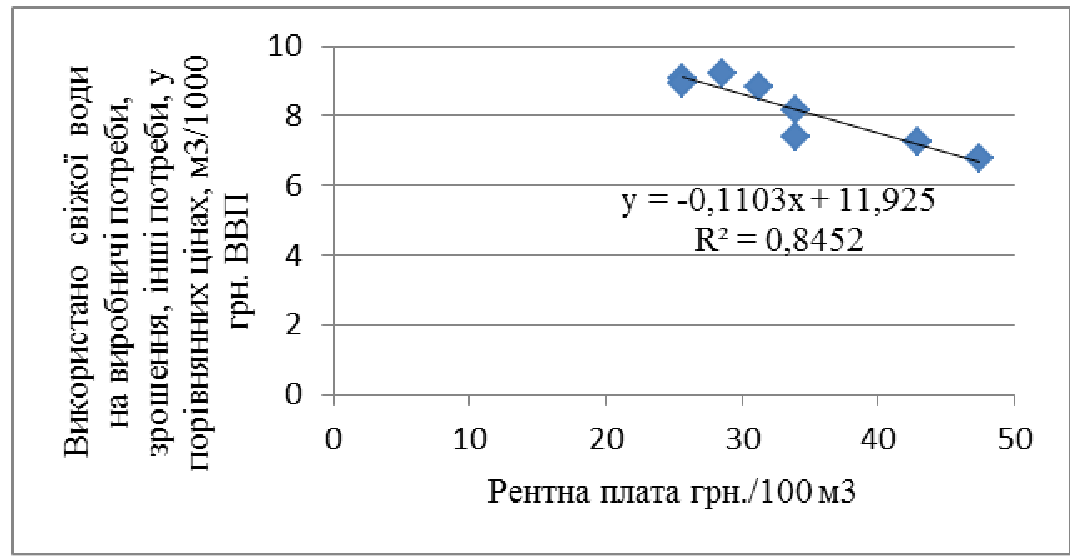

Рис. 4. Залежність обсягів споживання свіжої води на виробничі потреби від рентної плати на спец водокористування в Україні 


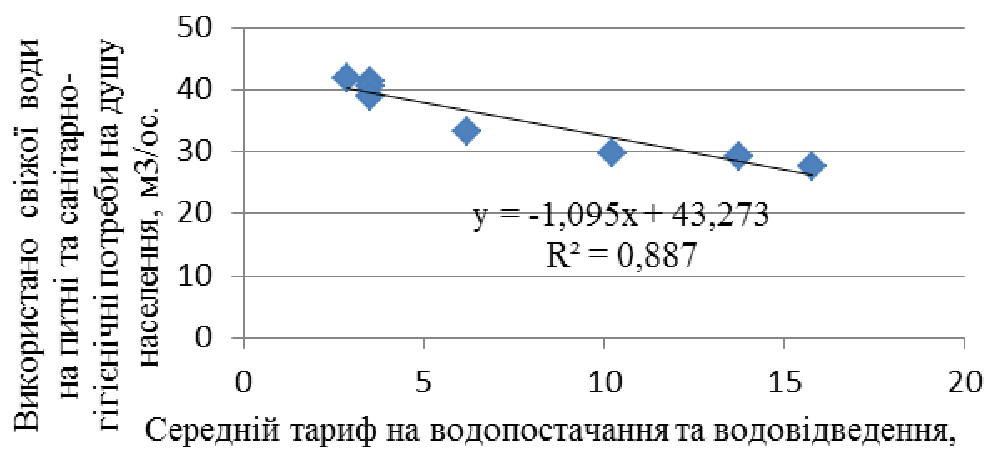

грн./M3

Рис. 5. Залежність обсягів споживання свіжої води на питні і санітарногігієнічні потреби від тарифів на водопостачання і водовідведення в Україні

Вихідні дані такого аналізу наведено в табл. 4 та 5: рентна плата для басейну р. Дніпро на південь від Києва і тарифи на водопостачання та водовідведення для м. Київ в будинках, обладнаних лічильником.

Таблиця 4

Вихідні дані до розрахунку еластичності попиту на воду за ціною 3 боку суб'єктів господарювання в Україні [11]

\begin{tabular}{|l|c|c|c|c|c|c|c|c|}
\hline \multicolumn{1}{|c|}{ Показники } & 2010 & 2011 & 2012 & 2013 & 2014 & 2015 & 2016 & 2017 \\
\hline $\begin{array}{l}\text { Використано свіжої } \\
\text { води на виробничі } \\
\text { потреби, зрошення, інші } \\
\text { потреби, у порівнянних } \\
\text { цінах, м } / 1000 \text { грн. ВВП }\end{array}$ & 8,927 & 9,208 & 8,844 & 8,173 & 7,406 & 7,276 & 6,786 \\
\hline $\begin{array}{l}\text { Рентна плата } \\
\text { грн./100 м }\end{array}$ & 25,65 & 25,65 & $28,55^{*}$ & $31,23^{*}$ & 33,916 & 33,92 & 42,91 & 47,37 \\
\hline
\end{tabular}

Примітка. ${ }^{*}$ - інтерпольовані дані

Таблиця 5

Вихідні дані до розрахунку еластичності попиту на воду за ціною 3 боку населення в Україні [18]

\begin{tabular}{|c|c|c|c|c|c|c|c|c|}
\hline Показники & 2010 & 2011 & 2012 & 2013 & 2014 & 2015 & 2016 & 2017 \\
\hline Використано & & & & & & & & \\
\hline $\begin{array}{ll}\text { води на питні та } \\
\text { санітарно-гігієнічні } \\
\text { потреби } \\
\text { населення, м³/ос. }\end{array}$ & 41,708 & $41,122^{*}$ & 40,497 & 38,746 & 33,021 & 29,514 & 28,975 & 27,569 \\
\hline $\begin{array}{l}\text { Середній тариф на } \\
\text { водопостачання та } \\
\text { водовідведення, грн./м³ }\end{array}$ & 2,87 & 3,5 & $3,5^{* *}$ & $3,5^{* *}$ & 6,22 & 10,24 & 13,77 & 15,792 \\
\hline
\end{tabular}

Примітка. ${ }^{*}$ - інтерпольовані дані, ${ }^{* *}$ - дані за попередній період 
За даними таблиць 4, 5 здійснено також розрахунки цінової еластичності попиту на воду в Україні. Так встановлено, що коефіці$\epsilon$ нт цінової еластичності попиту на воду виробничих підприємств $E=-0,452$, а попиту населення $E=-0,231$. Це означає, що як і в європейських країнах, попит на воду в Україні $€$ нееластичним за ціною, тобто слабко реагує на зміну ціни: внаслідок підвищення ціни на $1 \%$, попит на воду зменшується значно меншою мірою - тільки на 0,452 та $0,231 \%$ відповідно. Як наслідок, особливістю українського водоспоживання є більша нееластичність попиту на воду з боку домогосподарств, ніж з боку промисловості, сільського господарства, сфери послуг.

Встановлення факту нееластичності попиту на воду в Україні за ціною дає підстави зробити висновок, що для скорочення споживання води, крім цінових, варто застосовувати також нецінові механізми впливу на попит, особливо для стимулювання населення: субсидії, інформаційні кампанії щодо екологічних продуктів, щодо успішного досвіду економії води. Для бізнесу варто організувати торгівлю правами на забір води та ринок послуг із водопостачання, бенчмаркінг водоканалів та ОСББ, розвивати інноваційні технології зрошення, збору, очистки і використання дощової води, миття та транспортування продукції. Крім того, необхідно будувати та оновлювати існуючі очисні споруди та пристрої, де використовувати інноваційні та природні системи очистки.

3 іншого боку варто удосконалювати існуючі цінові механізми водокористування, усуваючи їхні недоліки:

1) запровадити прогресивну шкалу рентної плати та тарифів на воду (блочні тарифи);

2) збільшити прозорість обчислення плати/тарифів;

3) збільшити плату/тарифи для покриття витрат і створення інвестиційних ресурсів для постачальників води;

4) змінити фіскальний характер плати на цільовий - покриття витрат, інвестування в інфраструктуру водопостачальних організацій, здійснення природоохоронних заходів;

5) забезпечити повсюдний облік витрат води.

Висновки. Аналіз коефіцієнта еластичності попиту на воду за ціною дає підстави для Міністерства екології та природних ресурсів, яке відповідає за досягнення Цілей Сталого розвитку України та дотримання Водного кодексу, обгрунтувати напрями трансформування існуючих економічних механізмів з метою підвищення ефективності використання водних ресурсів. Основним напрямом може бути впровадження нецінових економічних механізмів, а також прогресивної шкали рентної плати та тарифів на воду, цільового призначення рен- 
тної плати. В подальших дослідженнях можна визначати еластичність попиту за доходом та виявляти кумулятивний вплив ціни і доходу на обсяги споживання водних ресурсів.

1. Про встановлення рамок діяльності Співтовариства в галузі водної політики: директива 2000/60/ЄС Європейського Парламенту і Ради від 23 жовтня 2000 року. Дата оновлення: 11.03.2008. URL: https://zakon.rada.gov.ua/ laws/show/994_962 (дата звернення: 27.03.2019). 2. Цілі Сталого Розвитку: Україна. Національна доповідь. Міністерство економічного розвитку і торгівлі України. 2017. 176 c. URL: http://www.un.org.ua/images/ SDGs_NationalReportUA_Web_1.pdf. (дата звернення: 15.05.2019). 3. Водний кодекс України. Дата оновлення: 18.12.2017. URL: https://zakon.rada.gov.ua/laws/show/213/95-\%D0\%B2\%D1\%80 (дата звернення: 27.03.2019). 4. Водні ресурси: використання, охорона, відтворення, управління : підручник для студентів вищих навч. закладів / А. В. Яцик, Ю. М. Грищенко, Л. А. Волкова, І. А. Пашенюк. К. : Генеза, 2007. 360 с. 5. Towards efficient use of water resources in Europe. EEA, Copenhagen, 2012. 74 p. URL: https://www.eea.europa.eu/ publications/towards-efficient-use-ofwater. (дата звернення: 15.05.2019). 6. Стадник М. Є. Оцінювання ефективності водокористування в Екраїні. Науковий вісник НЛтУ України. 2014. Вип. 24.10. C. 257-262. URL: http://www.irbis-nbuv.gov.ua/cgi-bin/ irbis_nbuv/cgiirbis_64.exe?I21DBN=LINK\&P21DBN=UJRN\&Z21ID=\&S21REF=1 $0 \& S 21 \mathrm{CNR}=20 \& S 21 \mathrm{STN}=1 \& \mathrm{~S} 21 \mathrm{FMT}=\mathrm{ASP} \_$meta\&C21 COM=S\&2_S21P03=FILA =\&2_S21STR=nvnltu_2014_24.10_45. (дата звернення: 15.05.2019). 7. G. Delacámara, Th. Dworak, C. M. Gómez, M. Lago, A. Maziotis, J. Rouillard, P. Strosser. Guidance: design and development of economic policy instruments in European water policy. December 2013. URL: http://www.feemproject.net/epiwater/docs/epi-water_guidance_v2.pdf. (дата звернення: 15.05.2019). 8. Pricing and non-pricing measures for managing water demand in Europe.

URL:

https://www.researchgate.net/publication/317585828_Pricing_and_nonpricing_measures_for_managing_water_demand_in_Europe. (дата звернення: 15.05.2019). 9. M. Lago, J. Moller-Gulland Evaluating Economic Policy Instruments for Sustainable Water Management in Europe. Review Reports. 20 December 2011. URL: http://www.feem-project.net/epiwater/docs/d32-d61/Deliverable\%203_1\%20and\%206__ 1\%20Intro.pdf. (дата звернення: 15.05.2019). 10. Options for decoupling economic growth from water use and water pollution. A report of the Water Working Group of the International Resource Panel. United Nations Environment Programme, 2015. URL: http://web.unep.org/ourplanet/may-2016/unep-publications/optionsdecoupling-economic-growth-water-use-and-water-pollution. (дата звернення: 15.05.2019). 11. Податковий кодекс України. Дата оновлення: 01.03.2019. URL: https://zakon.rada.gov.ua/laws/show/2755-17 (дата звернення: 27.03.2019). 12. Про затвердження Порядку формування тарифів на централізоване водопостачання та водовідведення : Постанова НКРЕКП від 
10.03.2016 № 302. Дата оновлення: 29.11.2017. URL: https://zakon.rada.gov.ua/laws/show/z0593-16 (дата звернення: 27.03.2019). 13. Тарифи у сфері централізованого водопостачання та водовідведення 2017. НКРЕКП, січень 2017. URL: https://www.slideshare.net/ NKREKP/201725012017. (дата звернення: 15.05.2019). 14. Довкілля України. Статистичний збірник $2017 . \quad$ URL: http://www.ukrstat.gov.ua/druk/publicat/kat_u/2018/zb/11 /zb_du2017.pdf. (дата звернення: 15.05.2019). 15. Статичний щорічник України 2017. URL: http://www.ukrstat.gov.ua/druk/publicat/kat_u/2018/zb/11/zb_seu2017_u.pd f. (дата звернення: 15.05.2019). 16. Water statistics on national level. URL: http://ec.europa.eu /eurostat/web/ environment/water/database?p_p_id= NavTreeportletprod_WAR_NavTreeportletprod_INSTANCE_wzV0grnD5Fb6\&p_ p_lifecycle $=0 \& p \_p \_s t a t e=$ normal\&p_p_mode $=$ view $\& p \_p \_c o l \_i d=c o l u m n-$

2\&p_p_col_pos=1\&p_p_col_count=2. (дата звернення: 15.05.2019). 17. Загальні показники використання водних ресурсів України: портал відкритих даних. URL: https://data.gov.ua /dataset/4dbbf2c6-3fea-40d7-899950c4d78a54ca. (дата звернення: 15.05.2019). 18. Тарифи ПрАТ «Київводоканал». URL: https://vodokanal.kiev.ua/rozraxunki-\%D1\%96-tarifi. (дата звернення: 15.05.2019).

\section{REFERENCES:}

1. Pro vstanovlennia ramok diialnosti Spivtovarystva $v$ haluzi vodnoi polityky: dyrektyva 2000/60/leS Yevropeiskoho Parlamentu i Rady vid 23 zhovtnia 2000 roku. Data onovlennia: 11.03.2008. URL: https://zakon.rada.gov.ua/ laws/show/994_962 (data zvernennia: 27.03.2019). 2. Tsili Staloho Rozvytku: Ukraina. Natsionalna dopovid. Ministerstvo ekonomichnoho rozvytku i torhivli Ukrainy. 2017. $176 \quad$ c. $\quad$ URL: http://www.un.org.ua/images/ SDGs_NationalReportUA_Web_1.pdf. (data zvernennia: 15.05.2019). 3. Vodnyi kodeks Ukrainy. Data onovlennia: 18.12.2017. URL: https://zakon.rada.gov.ua/laws/show/213/95-\%D0\%B2\%D1\%80 (data zvernennia: 27.03.2019). 4. Vodni resursy: vykory-stannia, okhorona, vidtvorennia, upravlinnia : pidruchnyk dlia studentiv vyshchykh navch. zakladiv / A. V. Yatsyk, Yu. M. Hryshchenko, L. A. Volkova, I. A. Pasheniuk. K. : Heneza, 2007. 360 s. 5. Towards efficient use of water resources in Europe. EEA, Copenhagen, 2012. 74 r. URL: https://www.eea.europa.eu/ publications/towards-efficient-use-of-water. (data zvernennia: 15.05.2019). 6. Stadnyk M. Ye. Otsiniuvannia efektyvnosti vodokorystuvannia v Ekraini. Naukovyi visnyk NLTU Ukrainy. 2014. Vyp. 24.10. C. 257-262. URL: http://www.irbisnbuv.gov.ua/cgi-bin/ bis_nbuv/cgiirbis_64.exe?|21DBN=LINK\&P21DBN=UJRN\&Z21ID=\&S21REF=10 $\& S 21 \mathrm{CNR}=20 \& S 21 \mathrm{STN}=1 \& S 21 \mathrm{FMT}=\mathrm{ASP} \_$meta\&C21COM=S\&2_S21P03=FILA= \&2_S21STR=nvnltu_2014_24.10_45. (data zvernennia: 15.05.2019). 7. G. Delacámara, Th. Dworak, C. M. Gómez, M. Lago, A. Maziotis, J. Rouillard, P. Strosser. Guidance: design and development of economic policy instruments 
in European water policy. December 2013. URL: http://www.feemproject.net/epiwater/docs/epi-water_guidance_v2.pdf. (data zvernennia: 15.05.2019). 8. Pricing and non-pricing measures for managing water demand in Europe.

URL:

https://www.researchgate.net/publication/317585828_Pricing_and_nonpricing_ measures_for_managing_water_demand_in_Europe. (data zvernennia: 15.05.2019). 9. M. Lago, J. Moller-Gulland Evaluating Economic Policy Instruments for Sustainable Water Management in Europe. Review Reports. 20 December 2011. URL: http://www.feem-project.net/epiwater/docs/d32-d61/Deliverable\%203_1\%20and\%206_1\%20Intro.pdf. (data zvernennia: 15.05.2019). 10. Options for decoupling economic growth from water use and water pollution. A report of the Water Working Group of the International Resource Panel. United Nations Environment Programme, 2015. URL: http://web.unep.org/ourplanet/may-2016/unep-publications/optionsdecoupling-economic-growth-water-use-and-water-pollution. (data zvernennia: 15.05.2019). 11. Podatkovyi kodeks Ukrainy. Data onovlennia: 01.03.2019. URL: https://zakon.rada.gov.ua/laws/show/2755-17 (data zvernennia: 27.03.2019). 12. Pro zatverdzhennia Poriadku formuvannia taryfiv na tsentralizovane vodopostachannia ta vodovidvedennia : Postanova NKREKP vid 10.03.2016 № 302. Data onovlennia: 29.11.2017. URL: https://zakon.rada.gov.ua/laws/show/z0593-16 (data zvernennia: 27.03.2019). 13. Taryfy u sferi tsentralizovanoho vodopostachannia ta vodovidvedennia 2017. NKREKP, sichen $2017 . \quad$ URL: https://www.slideshare.net/ NKREKP/201725012017. (data zvernennia: 15.05.2019). 14. Dovkillia Ukrainy. Statystychnyi zbirnyk 2017. URL: http://www.ukrstat.gov.ua/druk/publicat/kat_u/2018/zb/11 /zb_du2017.pdf. (data zvernennia: 15.05.2019). 15. Statychnyi shchorichnyk Ukrainy 2017. URL: http://www.ukrstat.gov.ua/druk/publicat/kat_u/2018/zb/11/zb_seu2017_u.pdf. (data zvernennia: 15.05.2019). 16. Water statistics on national level. URL: http://ec.europa.eu /eurostat/web/ environment/water/database?p_p_id= NavTreeportletprod_

WAR_NavTreeportletprod_INSTANCE_wzV0grnD5Fb6\&p_p_lifecycle=0\&p_p_st ate $=$ normal\&p_p_mode $=$ view\&p_p_col_id $=$ column-2\&p_p_col_pos $=$

1\&p_p_col_count=2. (data zvernennia: 15.05.2019). 17. Zahalni pokaznyky vykorystannia vodnykh resursiv Ukrainy: portal vidkrytykh danykh. URL: https://data.gov.ua /dataset/4dbbf2c6-3fea-40d7-8999-50c4d78a54ca. (data zvernennia: 15.05.2019). 18. Taryfy PrAT «Kyivvodokanal». URL: https://vodokanal.kiev.ua/rozraxunki-\%D1\%96-tarifi. (data zvernennia: 15.05.2019).

Рецензент: д.е.н., професор Савіна Н. Б. (НУВГП) 
Roshchyk I. A., Candidate of Economics (Ph.D.), Associate Professor (National University of Water and Environmental Engineering, Rivne)

\section{TRANSFORMATION OF ECONOMIC MECHANISMS FOR A MORE EFFICIENT WATER USE}

The essence of the concept "efficiency of water use" is investigated. Water resource efficiency is the ability of the system to obtain the maximum possible economic effect from the water resources use without damaging of environmental sustainability. The effectiveness of water use can be estimated by one of the interrelated indicators water use efficiency or water productivity. Improvement of efficiency is achieved through improving the structure of water use, economical spending of water resources and improving their quality.

Theoretical principles for transformation of economic mechanisms for a more efficient water use are generalized. If water demand is elastic to price it should be regulated mainly by price mechanisms (fees, tariffs, taxes, subsidies). If water demand is inelastic to price fees and tariffs should used to generate resources for covering current and capital costs for water supply. Non-price mechanisms should also actively used: water restriction, water trading, direct distribution of water saving technologies, information campaign, etc. The comparative analysis of water use efficiency in Ukraine and European countries is carried out. The water use efficiency of Ukraine is at least three times lower than in Europe.

One of the reasons for the low water use efficiency in Ukraine is the disadvantages of existing economic mechanisms for water demand managing: 1) fees for special water use (low, without progressive scale); 2) limits for special water use (overdone, administrative); 3) tariffs for water supply (do not stimulate the repair of networks, without progressive scale).

The price elasticity of water demand in Ukraine is determined. The water demand in Ukraine, as in European countries, is inelastic to price, especially the demand of the population. This means that a prices increase will not lead to a significant reduction in demand. The directions for transformation of economic mechanisms for a more efficient water use are formulated: implementation of non-pricing mechanisms, multi-level water fees and water tariffs, targeted use of water fees revenues.

Keywords: efficiency, water use efficiency, water productivity, price elasticity of water demand, water fee, water tariff, water licensing. 
Рощик И. А., к.э.н., доцент (Национальный университет водного хозяйства и природопользования, г. Ровно)

\section{TРАНСФОРМИРОВАНИЕ ЭКОНОМИЧЕСКИХ МЕХАНИЗМОВ ПОВЫШЕНИЯ ЭФФЕКТИВНОСТИ ИСПОЛЬЗОВАНИЯ ВОДНЫХ РЕСУРСОВ}

Исследована сущность понятия «эффективность использования водных ресурсов». Обобщены теоретические основы трансформации экономических механизмов водопользования с целью повышения его эффективности. Осуществлен сравнительный анализ эффективности использования водных ресурсов в Украине и странах Европы. Определена ценовая эластичность спроса на воду в Украине. Сформулированы направления трансформации экономических механизмов водопользования с целью повышения его эффективности: внедрение неценовых экономических механизмов, а также прогрессивной шкалы рентной платы и тарифов на воду, целевое использование поступлений от рентной платы.

Ключевые слова: эффективность, водоемкость, водоотдача, эластичность спроса, рентная плата, тариф, лимит. 